\title{
PREDICTION OF SHEAR STRENGTH OF SLENDER RC BEAMS WITHOUT SHEAR REINFORCEMENT
}

\author{
Chidananda $\mathbf{G}^{\mathbf{1}}$, Raviraj $\mathbf{S}^{\mathbf{2}}$ \\ ${ }^{I}$ Research Scholar, Department of Civil Engineering, Sri Jayachamarajendra College of Engineering, \\ Mysuru - 570 006, Karnataka, India. \\ ${ }^{2}$ Professor, Department of Civil Engineering, Sri Jayachamarajendra College of Engineering, Mysuru - 570 006, \\ Karnataka, India.
}

\begin{abstract}
This paper describes a study on shear strength of slender RC beams without shear reinforcement suggested by three shear evaluation methods viz. a proposed shear strength equation based on the fracture mechanics approach and two Indian codes of practice namely IS 456 (2000) and IRS 1997 (2003). Four hundred and fifty eight test beams selected from ACI-DAfStb database (2013) are considered for the study. The statistical analysis and demerit points classification indicate the proposed equation to show better estimate of shear strength of the test beams. Also the proposed equation captures well the influence of design parameters on shear strength of RC beams.
\end{abstract}

Keywords : Shear Strength, Fracture Mechanics, ACI-DAfStb Database (2013), Demerits Points Classification.

\section{INTRODUCTION}

Shear strength of RC beams is a debate subject of the century. Understanding shear behaviour of RC beams is quite complicated. Many investigators through experimental observation have proposed numerous theories on shear mechanism of RC beams. The shear in RC beams without shear reinforcement is resisted by uncracked concrete in the compression zone, aggregate interlock across the cracks and the dowel action of longitudinal reinforcement. Percentage of longitudinal reinforcement, compressive strength of concrete and effective depth of beam are important design parameters affecting the shear capacity of RC beams. The expressions for shear strength suggested in various standard codes of practice are empirical or semi empirical and consider the above design parameters to predict the shear strength with suitable safety and strength reduction factors.

\section{SHEAR STRENGTH PREDICTION BY THE SHEAR EVALUATION METHODS}

Three shear evaluation methods viz. a proposed shear strength equation based on the fracture mechanics approach and the shear strength suggested by two Indian codes of practice namely IS 456 (2000) and IRS Code 1997 (2003) are considered in the present study. The expressions for shear strength suggested in these shear evaluation methods are as follows.

\section{(i) Proposed Shear Strength Equation}

Based on fracture mechanics approach, Chidananda and Raviraj (2016) proposed Eq. 1 for shear strength of RC beams without shear reinforcement
$* * *$

$$
\begin{array}{ll}
v_{u}=\frac{2}{3} f_{c t m}\left[3.09\left(p_{t}\right)^{0.31}\left(f_{c k}\right)^{-0.40}(d)^{-0.34}\left(f_{s y k}\right)^{0.22}\right]+ \\
\frac{0.23\left(p_{t}\right)^{8 / 9}\left(f_{c k}+4\right)^{1 / 3}}{(d)^{1 / 3}} & \\
\text { where, } & \text { if } f_{c k} \leq 50 \mathrm{MPa} \\
f_{c t m}=0.3 f_{c k}^{2 / 3} & \text { if } f_{c k}>50 \mathrm{MPa} \\
f_{c t m}=2.12 \ln \left(1+0.1 f_{c m}\right) & \\
p_{t} \ngtr 3 \% & \\
f_{c k} \ngtr 60 \mathrm{MPa} & \\
f_{s y k} \ngtr 1000 \mathrm{MPa} &
\end{array}
$$

The first term in Eq. 1 represents the shear carried by concrete over the effective shear depth which includes the shear mechanisms of uncracked concrete and aggregate interlocking effect across the smeared crack. The second term represents the shear carried by the dowel action of longitudinal reinforcement as suggested by Reineck (1991). Further, Eq. 1 is modified to obtain the design shear strength equation $v_{u d}=\emptyset_{v} v_{u}$, where $\emptyset_{v}=0.75$ is the shear strength reduction factor.

[Remarks : in S.I. units]

(ii) IS 456 (2000) and SP 24 (S\&T) (1983) (Bureau of Indian Standards)

Clause 40.2 of IS 456 (2000) and Clause 39.2 of SP 24 (S\&T) (1983) suggests the design shear strength $\tau_{c}$ of concrete in RC beams without shear reinforcement as

$\tau_{c}=\frac{0.85 \sqrt{0.8 f_{c k, c u}}(\sqrt{1+5 \beta}-1)}{6 \beta} \leq \tau_{c, \max }$ 
where,

$\beta=\frac{0.8 f_{c k, c u}}{6.89 P_{t}} \nless 1$

$f_{c k, c u} \ngtr 40 \mathrm{MPa}$

$p_{t} \ngtr 3 \%$

$\tau_{c, \max }=0.85\left[0.83 \sqrt{0.8 f_{c k, c u}}\right]$

The factor 0.8 in the formulae is for converting cylinder strength to cube strength and 0.85 is a reduction factor similar to partial safety factor $\gamma_{m}$ for materials.

[Remarks : in S.I. units]

\section{(iii) IRS 1997 (2003) (Indian Railway Standard)}

Clause 15.4.3 of IRS 1997 (2003) discusses the ultimate shear stress $v_{c}$ of concrete in RC beams without shear reinforcement and is given by

$v_{c}=\frac{0.27}{\gamma_{m}}\left(\frac{100 A_{s}}{b_{w} d}\right)^{1 / 3}\left(f_{c k, c u}\right)^{1 / 3}$

where,

$\frac{100 A_{s}}{b_{w} d} \ngtr 3 \%$

$f_{c k, c u} \ngtr 40 \mathrm{MPa}$ $\gamma_{m}=1.25$

[Remarks : in S.I. units]

\section{SELECTION OF TEST BEAMS CONSIDERED FOR THE STUDY}

A total of 458 slender simply supported RC test beams without shear reinforcement are selected from ACI-DAfStb database (2013) to study the performance of the considered shear evaluation methods. The selected beams satisfy the following criteria.

1. Rectangular in cross section having reinforcement only at the tension side.

2. Percentage of reinforcement $p_{t}$ upto $3 \%$.

3. Characteristic cylinder compressive strength of concrete $f_{c k}$ in between 12 and $60 \mathrm{MPa}$.

4. Characteristic yield strength of reinforcing steel $f_{\text {syk }}$ upto $1000 \mathrm{MPa}$.

Table 1 shows the list of investigators of 458 test beams selected from ACI-DAfStb database (2013).

Table 1 : List of Investigators of selected 458 test beams

\begin{tabular}{|c|c|c|c|}
\hline Sl. No. & Investigators & Sl. No. & Investigators \\
\hline 1 & Ahmad et al. (1986) (2) & 29 & Leonhardt and Walther (1962) (27) \\
\hline 2 & Angelakos et al. (2001) (5) & 30 & Marti et al. (1977) (2) \\
\hline 3 & Aster and Koch (1974) (5) & 31 & Mathey and Watstein (1963) (9) \\
\hline 4 & Lubell et al. (2004) (9) & 32 & Moody et al. (1954) (21) \\
\hline 5 & Bernander (1957) (6) & 33 & Morrow and Viest (1957) (9) \\
\hline 6 & Bhal (1968) (8) & 34 & Mphonde and Frantz (1984) (1) \\
\hline 7 & Bresler and Scordelis (1963) (3) & 35 & Niwa et al. (1987) (3) \\
\hline 8 & $\begin{array}{l}\text { Cladera and Mari (2002), } \\
\text { Cladera (2002) (3) }\end{array}$ & 36 & Podgorniak-Stanik (1998) (3) \\
\hline 9 & Chana (1981) (23) & 37 & Rajagopalan and Ferguson (1968) (5) \\
\hline 10 & Chang and Kesler (1958) (15) & 38 & Regan (1971) (4) \\
\hline 11 & Collins and Kuchma (1999) (5) & 39 & Rehm et al. (1978) (1) \\
\hline 12 & Diaz de Cossio and Siess (1960) (2) & 40 & Rosenbusch and Teutsch (2002) (3) \\
\hline 13 & Elzanaty et al. (1986) (6) & 41 & Rusch et al. (1962) (3) \\
\hline 14 & Ferguson (1956) (1) & 42 & Salandra and Ahmad (1989) (2) \\
\hline 15 & Ghannoum (1998) (10) & 43 & Taylor (1968) (8) \\
\hline 16 & Hallgren (1994) (8) & 44 & Taylor (1972) (5) \\
\hline 17 & Hamadi (1976) (4) & 45 & Walraven (1978) (3) \\
\hline 18 & Hanson (1958) (3) & 46 & Xie et al. (1994) (1) \\
\hline 19 & Hanson (1961) (4) & 47 & Lubell (2006) (7) \\
\hline 20 & Hedmann and Losberg (1978) (4) & 48 & Sherwood (2008) (8) \\
\hline 21 & Kani (1967) (41) & 49 & Thiele (2010) (5) \\
\hline 22 & Kani et al. (1979) (63) & 50 & Winkler (2011) (5) \\
\hline 23 & Kawano and Watanabe (1998) (2) & 51 & $\begin{array}{l}\text { Tureyen (2001), } \\
\text { Tureyen and Frosch (2002) (3) }\end{array}$ \\
\hline 24 & Kim and Park (1994) (14) & 52 & Bentz and Buckley (2005) (9) \\
\hline 25 & Krefeld and Thurston (1966) (28) & 53 & Krefeld and Thurston (1966) (12) \\
\hline 26 & Kung (1985) (5) & 54 & Leonhardt and Walther (1962) (6) \\
\hline 27 & Kulkarni and Shah (1998) (4) & 55 & Shioya (1989) (3) \\
\hline 28 & Laupa et al. (1953) (2) & 56 & Iguro et al. (1985) (5) \\
\hline
\end{tabular}


In Table 1, the values in the first and the second parentheses indicate the year of testing and the number of selected beams of the investigators respectively. Among the selected 458 test beams, 432 beams are subjected to either mid point or two point loadings and the remaining 26 beams, tested by the last four investigators (Sl. No. 53 to 56), are subjected to uniformly distributed loading. Table 2 shows the consolidated limits for various parameters of selected 458 test beams.

Table 2 : Consolidated limits for the parameters of selected 458 test beams

\begin{tabular}{|c|c|c|c|c|}
\hline $\begin{array}{c}\text { Sl. } \\
\text { No. }\end{array}$ & Parameter & Unit & Minimum & Maximum \\
\hline 1 & $b$ & $\mathrm{~mm}$ & 50 & 3005 \\
\hline 2 & $d$ & $\mathrm{~mm}$ & 65 & 3000 \\
\hline 3 & $a / d$ & - & 2.4 & 8.1 \\
\hline 4 & $p_{t}$ & $(\%)$ & 0.139 & 2.890 \\
\hline 5 & $f_{c k}$ & $\mathrm{MPa}$ & 12.27 & 59.45 \\
\hline 6 & $f_{s y k}$ & $\mathrm{MPa}$ & 228.18 & 908.18 \\
\hline
\end{tabular}

\section{STATISTICAL ANALYSIS OF THE SHEAR EVALUATION METHODS}

Unit partial safety factors, unit reduction factors and suitable conversion factors for characteristic concrete compressive strength and characteristic yield strength of reinforcing steel given in Appendix A are applied to the expressions suggested in the three considered shear evaluation methods to predict the shear strength $\left(V_{\text {pre }}\right)$ of selected 458 test beams. The predicted shear strengths are compared with the corresponding experimental shear strength $\left(V_{\text {test }}\right)$ results. The statistical results are summarized in Fig. 1 and Table 3.

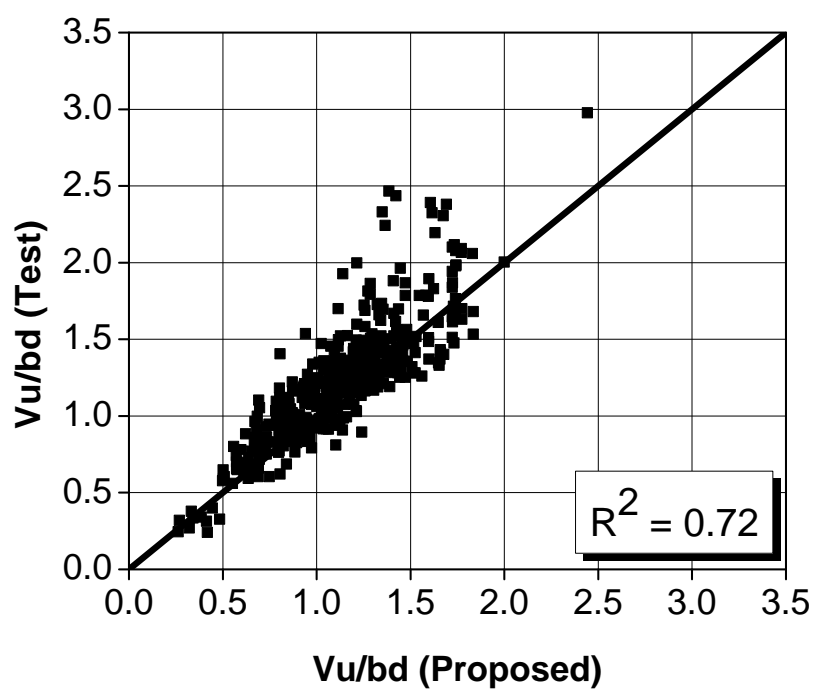

(a)

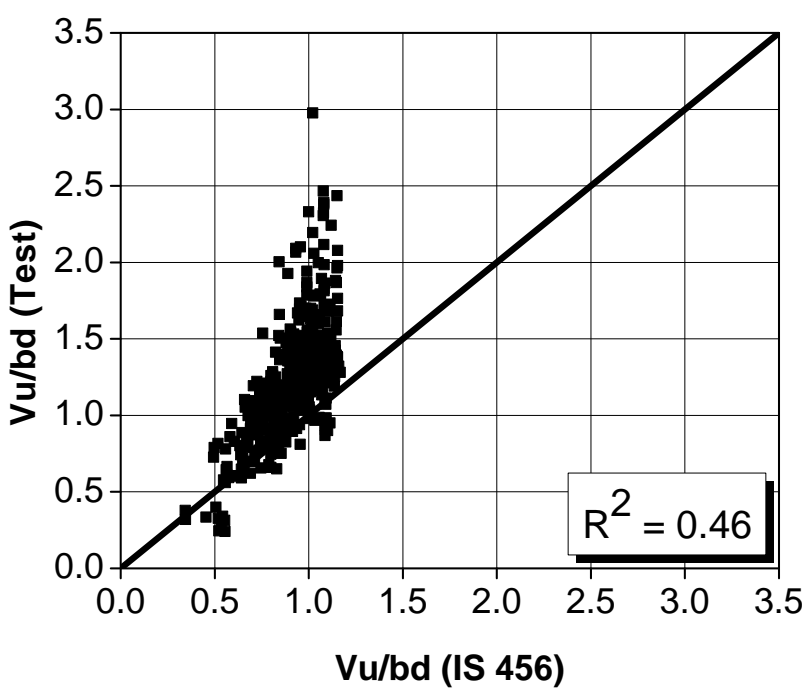

(b)

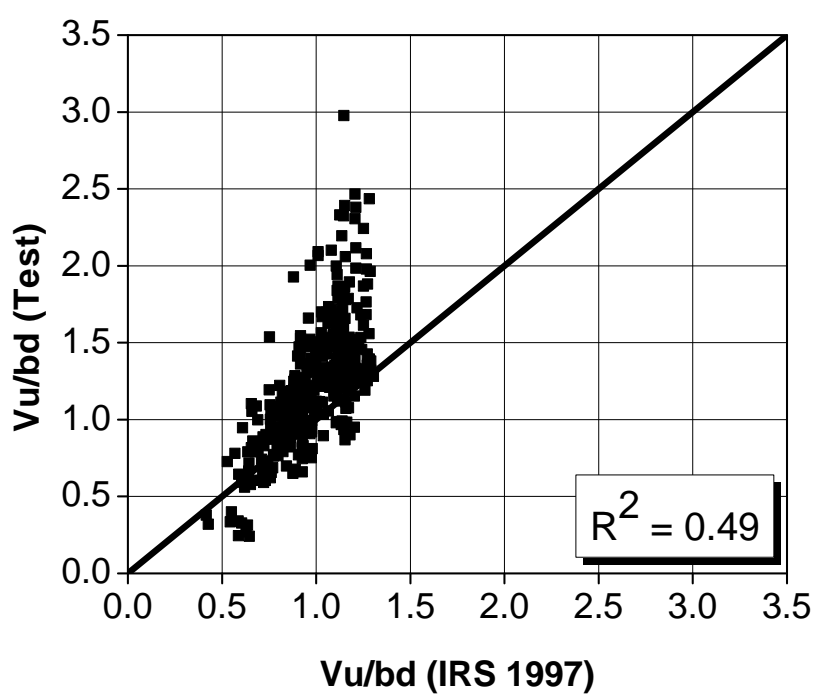

(c)

Fig. 1 [(a) to (c)]: Correlation between the prediction from shear evaluation methods and the test results of selected 458 test beams

Table 3 : Statistical results of the shear evaluation methods

\begin{tabular}{|c|l|c|c|c|}
\hline \multirow{2}{*}{$\begin{array}{c}\text { S1. } \\
\text { No. }\end{array}$} & $\begin{array}{l}\text { Shear } \\
\text { evaluation } \\
\text { method }\end{array}$ & $\left(\frac{V_{\text {test }}}{V_{\text {pre }}}\right)_{\text {Average }}$ & $\begin{array}{c}\text { Statistical results } \\
\text { Standard } \\
\text { deviation }\end{array}$ & $\begin{array}{c}\text { Coefficient } \\
\text { of } \\
\text { Variation } \\
(\mathrm{CV}) \\
(\%)\end{array}$ \\
\hline 1 & $\begin{array}{l}\text { Proposed } \\
\text { equation }\end{array}$ & 1.10 & 0.17 & 15.45 \\
\hline 2 & $\begin{array}{l}\text { IS 456 } \\
(2000)\end{array}$ & 1.34 & 0.30 & 22.39 \\
\hline 3 & $\begin{array}{l}\text { IRS 1997 } \\
(2003)\end{array}$ & 1.23 & 0.27 & 21.95 \\
\hline
\end{tabular}


From Fig. 1 and Table 3, it is inferred that the shear predicted by the proposed shear strength equation shows a better correlation with a correlation coefficient $R^{2}$ of 0.72 , and an average $\left(V_{\text {test }} / V_{\text {pre }}\right)$ ratio of 1.10 and a low $\mathrm{CV}$ of $15.45 \%$ in predicting the shear strength of selected 458 test beams than the two Indian codes of practice.

\section{DEMERIT POINTS CLASSIFICATION}

The demerit points classification suggested by Collins (2001) measures agreement between $V_{\text {test }}$ and $V_{\text {pre }}$. In this classification, the ratio $\frac{V_{\text {test }}}{V_{\text {pre }}}$ is calculated for each of the beam in the database. A demerit point value as given in Table 4 is assigned to each beam which depends on $\frac{V_{\text {test }}}{V_{\text {pre }}}$ ratio. The summation of the demerit points of all the beams shows the overall performance of the shear evaluation method. A smaller summation indicates the shear evaluation method to be more reliable in predicting the shear strength.

Table 4 : Collins (2001) demerit points classification

\begin{tabular}{|c|l|c|c|}
\hline $\begin{array}{c}\text { Sl. } \\
\text { No. }\end{array}$ & \multicolumn{1}{|c|}{ Classification } & $\frac{V_{\text {test }}}{V_{\text {pre }}}$ & Demerit points \\
\hline 1 & Extremely dangerous & $<0.50$ & 10 \\
\hline 2 & Dangerous & $0.50-0.65$ & 5 \\
\hline 3 & Low safety & $0.65-0.85$ & 2 \\
\hline 4 & Appropriate safety & $0.85-1.30$ & 0 \\
\hline 5 & Conservative & $1.30-2.00$ & 1 \\
\hline 6 & Extremely conservative & $>2.00$ & 2 \\
\hline
\end{tabular}

The demerit points classification is applied to evaluate the performance of the three shear evaluation methods in predicting the shear strength of selected 458 test beams. The demerit points value of the shear evaluation methods for each classification are summarized in Table 5. A low value of 'Total demerit points' of the proposed shear strength equation indicates that it performs well in predicting the shear strength than the two Indian codes of practice.

Table 5 : Demerit points value of the shear evaluation methods

\begin{tabular}{|c|c|c|c|c|c|c|c|c|}
\hline \multirow{2}{*}{$\begin{array}{l}\text { Sl. } \\
\text { No. }\end{array}$} & \multirow{2}{*}{ Shear evaluation method } & \multicolumn{6}{|c|}{$\frac{V_{\text {test }}}{V_{\text {pre }}}$} & \multirow{2}{*}{$\begin{array}{c}\text { Total } \\
\text { demerit } \\
\text { points }\end{array}$} \\
\hline & & $<0.50$ & $\begin{array}{c}0.50 \\
\text { to } \\
0.65\end{array}$ & $\begin{array}{c}0.65 \\
\text { to } \\
0.85\end{array}$ & $\begin{array}{c}0.85 \\
\text { to } \\
1.30\end{array}$ & $\begin{array}{l}1.30 \\
\text { to } \\
2.00\end{array}$ & $>2.00$ & \\
\hline 1 & Proposed equation & 0 & 1 & 24 & 381 & 52 & 0 & 105 \\
\hline 2 & IS 456 (2000) & 2 & 4 & 9 & 218 & 210 & 15 & 298 \\
\hline 3 & IRS 1997 (2003) & 4 & 3 & 21 & 289 & 131 & 10 & 248 \\
\hline
\end{tabular}

\section{PARAMETRIC STUDIES}

Parametric studies are carried out to study the influence of the design parameters viz. $p_{t}, f_{c k}$ and $d$ on shear strength of RC beams predicted by the shear evaluation methods considering respectively a few beams tested of Krefeld and Thurston (1966) and Kani et al. (1979); Moody et al. (1954) and Sherwood (2008); and Bhal (1968) and Walraven
(1978). The details of the RC beams considered for the parametric study are tabulated in Appendix B. Comparison of shear predicted by the shear evaluation methods with the test results, for the three design parameters, are shown in Fig. 2. It is inferred that the proposed shear strength equation shows better agreement with the test results than the two Indian codes of practice. 


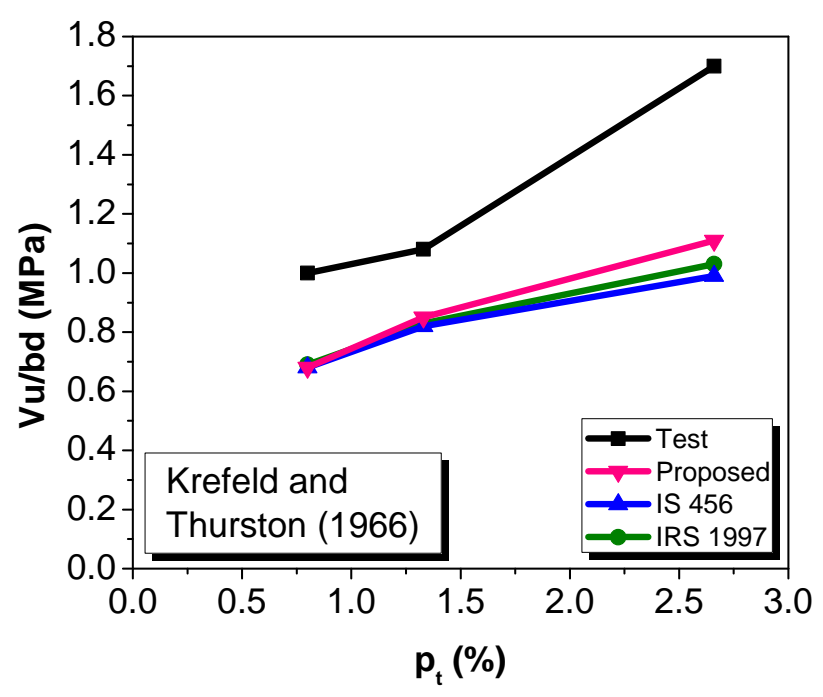

(a)

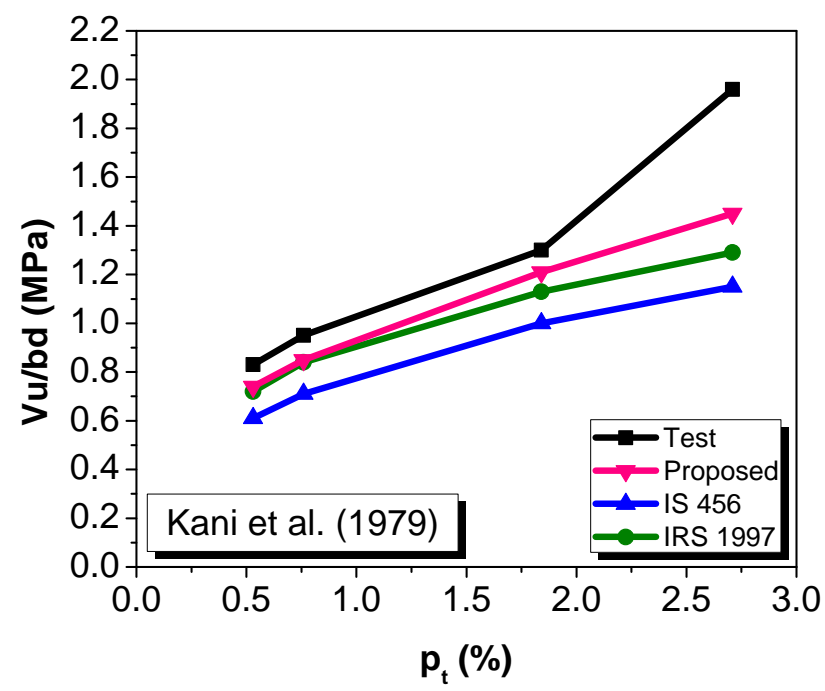

(b)

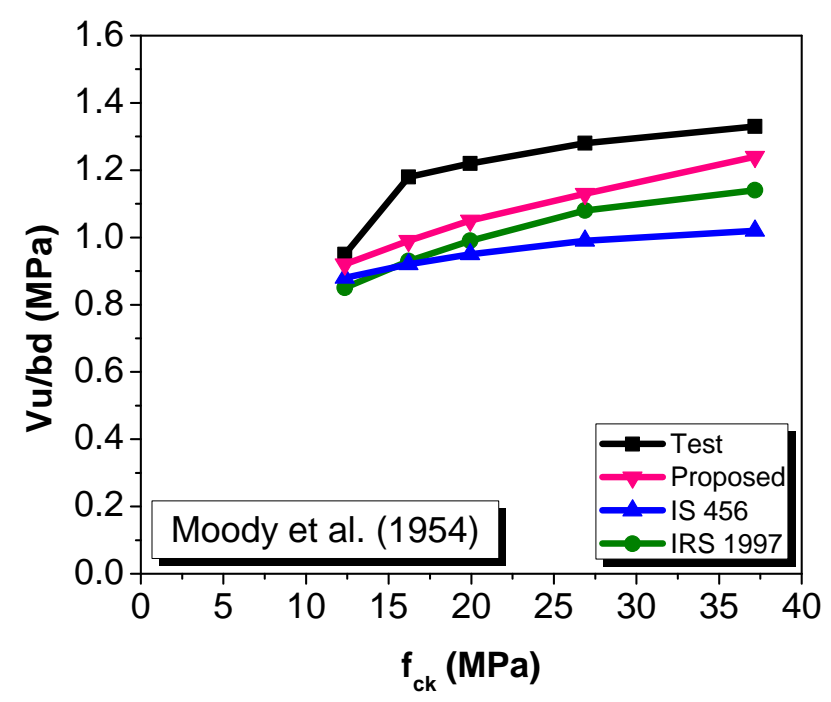

(c)

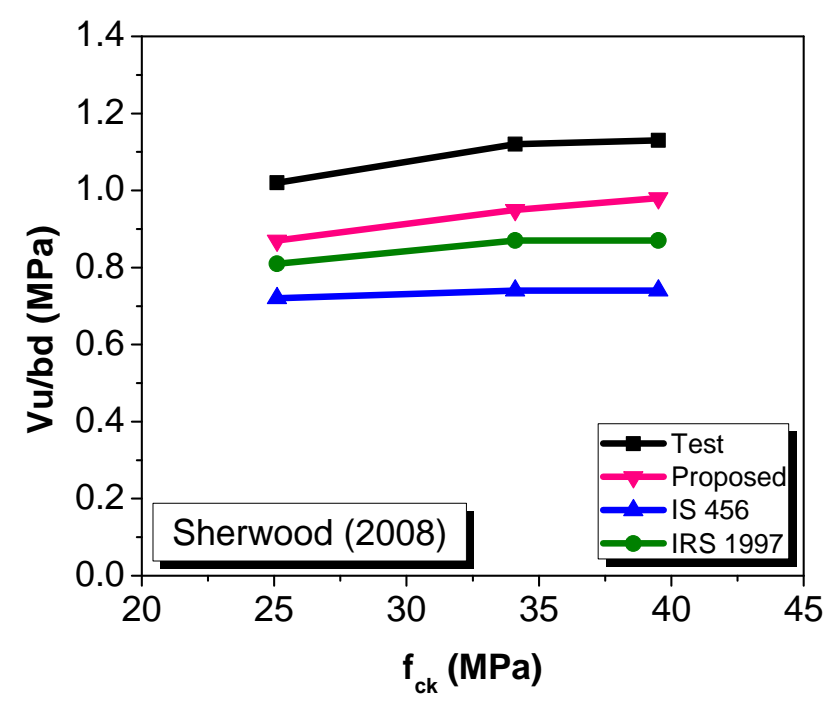

(d)

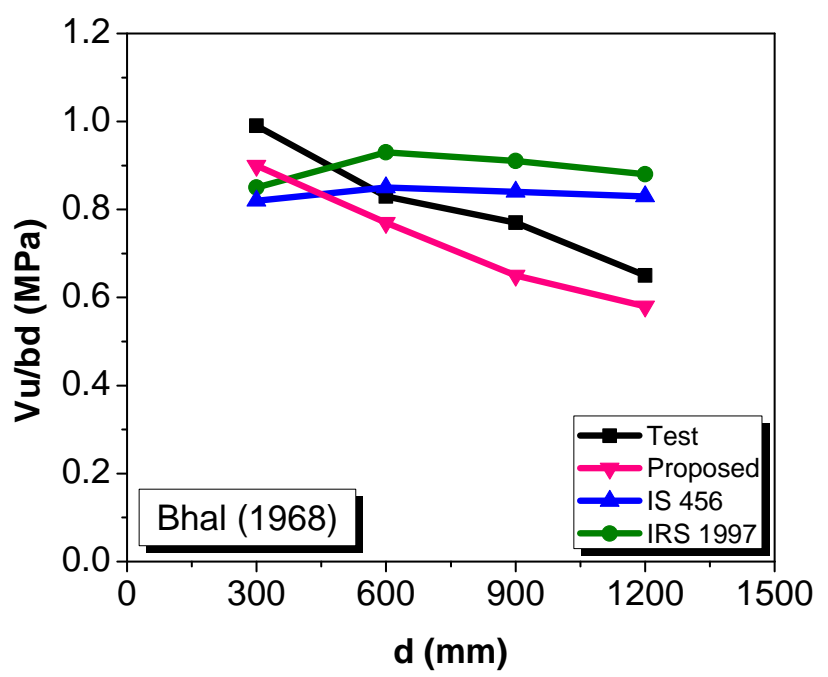

(e)

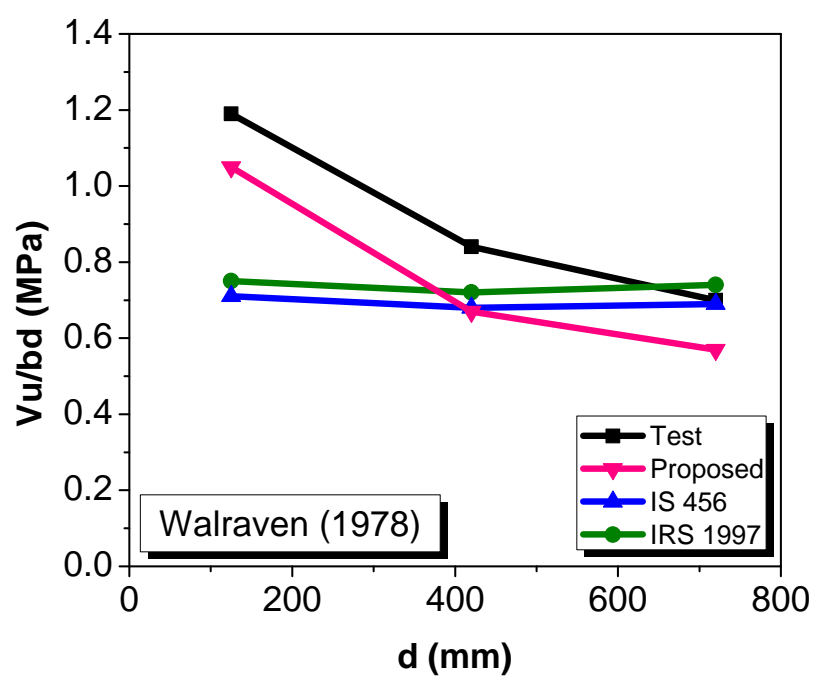

(f)

Fig. 2 [(a) to (f)]: Comparison of the shear predicted by shear evaluation methods with the test results of Krefeld and Thurston (1966), Kani et al. (1979), Moody et al. (1954), Sherwood (2008), Bhal (1968) and Walraven (1978) 


\section{CONCLUSIONS}

The study presents the prediction of shear strength of selected 458 slender RC beams without shear reinforcement by three shear evaluation methods viz. a proposed shear strength equation based on the fracture mechanics approach and two Indian codes of practice namely IS 456 (2000) and IRS 1997 (2003). The following conclusions are drawn.

1. The statistical analysis and demerit points classification indicate that the shear strength predicted by the proposed equation agrees fairly well with the test results, whereas IS 456 (2000) and IRS 1997 (2003) predict the shear strength conservatively.

2. The comparison with the test results of Krefeld and Thurston (1966) and Kani et al. (1979); Moody et al. (1954) and Sherwood (2008); and Bhal (1968) and Walraven (1978) shows that the influence of design parameters viz. $p_{t}, f_{c k}$ and $d$ on shear carrying capacity is well captured by the proposed equation than the two Indian codes of practice.

3. It is suggested to consider the proposed equation for evaluating the shear strength of RC beams without shear reinforcement for practical design than the two Indian codes of practice.

\section{NOTATION}

\begin{tabular}{|c|c|}
\hline$a$ & Shear span \\
\hline$b$ & Width of beam \\
\hline$d$ & Effective depth of beam \\
\hline$a / d$ & Shear span to effective depth ratio \\
\hline$f_{c, c u}$ & $\begin{array}{l}\text { Mean cube }(150 \mathrm{~mm}) \text { compressive strength of } \\
\text { concrete }\end{array}$ \\
\hline$f_{c k}$ & $\begin{array}{l}\text { Characteristic cylinder }(150 \times 300 \mathrm{~mm}) \\
\text { compressive strength of concrete }\end{array}$ \\
\hline$f_{c k, c u}$ & $\begin{array}{l}\text { Characteristic cube }\left(\begin{array}{lll}150 & \mathrm{~mm}\end{array}\right) \text { compressive } \\
\text { strength of concrete }\end{array}$ \\
\hline$f_{c m}$ & $\begin{array}{l}\text { Mean cylinder }(150 \times 300 \mathrm{~mm}) \text { compressive } \\
\text { strength of concrete }\end{array}$ \\
\hline$f_{c t m}$ & Mean axial tensile strength of concrete \\
\hline$f_{l c, c u}$ & $\begin{array}{l}\text { Uniaxial compressive strength of concrete derived } \\
\text { from } f_{c, c u}\end{array}$ \\
\hline$f_{l c, c y l}$ & $\begin{array}{l}\text { Uniaxial compressive strength of concrete derived } \\
\text { from } f_{c m}\end{array}$ \\
\hline$f_{s y}$ & Yield strength of reinforcing steel \\
\hline$f_{\text {syk }}$ & $\begin{array}{l}\text { Characteristic yield strength of reinforcing steel } \\
\text { (i.e. Grade of steel) }\end{array}$ \\
\hline$p_{t}$ & Percentage of reinforcement \\
\hline$D$ & Overall depth of beam \\
\hline$V_{\text {pre }}$ & Predicted shear strength \\
\hline$V_{\text {test }}$ & Experimental shear strength \\
\hline
\end{tabular}

\section{REFERENCES}

[1] Chidananda G. and Raviraj S. (2016), "Fracture Mechanics Model for Prediction of Shear Strength of Slender RC Beams without Shear Reinforcement", Communicated to "Frontiers of Structural and Civil Engineering".
[2] Collins M.P. (2001), "Evaluation of Shear Design Procedures for Concrete Structures-A Report Prepared for the CSA Technical Committee on Reinforced Concrete Design, Canada".

[3] Reineck K.H. (1991), "Ultimate Shear Force of Structural Concrete Members without Transverse Reinforcement Derived from a Mechanical Model", ACI Structural Journal, Vol. 88, No. 5, pp. 592-602.

[4] Reineck K.H., Kuchma D.A. and Fitik B. (2010), "Extended Databases with Shear Tests on Structural Concrete Beams without and with Stirrups for the Assessment of Shear Design Procedures-Research Report", Institute for Lightweight Structures Conceptual and Structural Design (ILEK), University of Stuttgart and University of Illinois.

[5] Reineck K.H., Bentz E.C., Fitik B., Kuchma D.A. and Bayrak O. (2013), "ACI-DAfStb Database of Shear Tests on Slender Reinforced Concrete Beams without Stirrups", ACI Structural Journal, Vol. 110, No. 5, pp. 867-876.

[6] IS 456 (2000), "Plain and Reinforced Concrete-Code of Practice", Bureau of Indian Standards, New Delhi, India.

[7] SP 24 (S\&T) (1983), "Explanatory Handbook on Indian Standard Code of Practice for Plain and Reinforced Concrete (IS : 456-1978)", Bureau of Indian Standards, New Delhi, India.

[8] Indian Railway Standard-1997 (2003), "Code of Practice for Plain, Reinforced \& Prestressed Concrete for General Bridge Construction" (Concrete Bridge Code), Research Designs and Standards Organization, Lucknow, India.

\section{Appendix A}

Conversion factors for characteristic concrete compressive strength and characteristic yield strength of reinforcing steel

\section{Concrete :}

a. Cylinder compressive strength [Reineck et al. (2010)] $f_{c k}=f_{c m}-\Delta f$, where $\Delta f=4 \mathrm{MPa}$ (for laboratory conditions) $f_{l c, c y l}=0.95 f_{c m}$

b. Cube compressive strength [Reineck et al. (2010)]

$f_{l c, c u}=0.79 f_{c, c u}$

if $f_{c m} \leq 54 \mathrm{MPa}$

$f_{l c, c u}=0.95 f_{c, c u}-10.5$

if $f_{c m}>54 \mathrm{MPa}$

c. Relation between cylinder and cube compressive strengths are obtained by equating uniaxial compressive strengths.

d. $f_{c k, c u}=f_{c, c u}-3$ [ from Clause 16.1 of IS 456 (2000) for compliance requirement]

\section{Reinforcing steel :}

$f_{s y k}=\frac{f_{s y}}{1.1}[$ Reineck et al. (2010)] 
Appendix B

Details of RC beams for the study of design parameters

\begin{tabular}{|c|c|c|c|c|c|c|c|c|}
\hline $\begin{array}{l}\text { Sl. } \\
\text { No. }\end{array}$ & $\begin{array}{c}\text { Specimen } \\
\text { Nomenclature }\end{array}$ & $\begin{array}{c}b \\
(\mathrm{~mm})\end{array}$ & $d(\mathrm{~mm})$ & $a / d$ & $\begin{array}{l}p_{t} \\
(\%)\end{array}$ & $\begin{array}{c}f_{s y} \\
(\mathrm{MPa})\end{array}$ & $\begin{array}{l}f_{l c, c y l} \\
(\mathrm{MPa})\end{array}$ & $\begin{array}{l}V_{\text {test }} \\
(\mathrm{kN})\end{array}$ \\
\hline \multicolumn{9}{|c|}{ Krefeld and Thurston (1966) - Influence of $p_{t}$} \\
\hline 1 & IV-13A2 & 152.4 & 319 & 2.67 & 0.798 & 366 & 18.93 & 48.48 \\
\hline 2 & 15B2 & 152.4 & 316 & 2.69 & 1.332 & 386 & 19.66 & 52.04 \\
\hline 3 & $18 \mathrm{E} 2$ & 152.4 & 316 & 2.69 & 2.664 & 386 & 18.80 & 81.84 \\
\hline \multicolumn{9}{|c|}{ Kani et al. (1979) - Influence of $p_{t}$} \\
\hline 4 & 179 & 153.2 & 264.2 & 2.57 & 0.526 & 400 & 30.73 & 33.58 \\
\hline 5 & 163 & 156.0 & 272.5 & 2.49 & 0.756 & 378 & 33.61 & 40.48 \\
\hline 6 & 197 & 150.4 & 273.6 & 2.48 & 1.835 & 376 & 34.20 & 53.38 \\
\hline 7 & 214 & 153.4 & 271.8 & 2.50 & 2.708 & 412 & 34.20 & 81.84 \\
\hline \multicolumn{9}{|c|}{ Moody et al. (1954) - Influence of $f_{c k}$} \\
\hline 8 & 16 & 152.4 & 268.2 & 3.41 & 1.898 & 310 & 15.53 & 38.83 \\
\hline 9 & 12 & 152.4 & 268.2 & 3.41 & 1.898 & 310 & 19.20 & 48.17 \\
\hline 10 & 10 & 152.4 & 268.2 & 3.41 & 1.898 & 310 & 22.73 & 49.95 \\
\hline 11 & 7 & 152.4 & 268.2 & 3.41 & 1.898 & 310 & 29.35 & 52.17 \\
\hline 12 & 9 & 152.4 & 268.2 & 3.41 & 1.898 & 310 & 39.11 & 54.40 \\
\hline \multicolumn{9}{|c|}{ Sherwood (2008) - Influence of $f_{c k}$} \\
\hline 13 & $\mathrm{~S}-40 \mathrm{~N} 2$ & 122 & 280 & 2.78 & 0.835 & 494 & 27.65 & 34.86 \\
\hline 14 & S-20 N1 & 122 & 280 & 2.78 & 0.835 & 494 & 37.24 & 39.16 \\
\hline 15 & $\mathrm{~S}-50 \mathrm{~N} 2$ & 122 & 280 & 2.78 & 0.835 & 494 & 41.33 & 40.58 \\
\hline \multicolumn{9}{|c|}{ Bhal (1968) - Influence of $d$} \\
\hline 16 & B1 & 240.0 & 300.0 & 2.94 & 1.257 & 426 & 22.02 & 70.99 \\
\hline 17 & B2 & 240.0 & 600.0 & 2.94 & 1.257 & 426 & 28.12 & 119.48 \\
\hline 18 & B3 & 240.0 & 900.0 & 2.94 & 1.257 & 426 & 26.11 & 166.38 \\
\hline 19 & B4 & 240.0 & 1200.0 & 2.94 & 1.257 & 426 & 23.95 & 187.10 \\
\hline \multicolumn{9}{|c|}{ Walraven (1978) - Influence of $d$} \\
\hline 20 & A1 & 200 & 125 & 3 & 0.829 & 440 & 22.90 & 29.80 \\
\hline 21 & $\mathrm{~A} 2$ & 200 & 420 & 3 & 0.741 & 440 & 22.90 & 70.60 \\
\hline 22 & A3 & 200 & 720 & 3 & 0.792 & 440 & 23.20 & 100.80 \\
\hline
\end{tabular}

